International Journal of Islamic Educational Psychology

Vol. 1, No. 2, December 2020

DOI: https://doi.org/10.18196/ijiep.v1i2.9736

\title{
Evaluation of Madaris Curriculum Integration for Primary Muslim Education in Mindanao: An Assessment of The Influence of Psychology
}

\author{
${ }^{1}$ Kamarodin Abas Abdulkarim*, ${ }^{2}$ Fitriah M. Suud \\ ${ }^{1}$ Western Mindanao State University, Philippines \\ ${ }^{2}$ Universitas Muhammadiyah Yogyakarta, Indonesia \\ *Corresponding email: kamarabdulkarim915@gmail.com
}

\section{ARTICLE INFO}

Article history

Received, 05/09/2020

Revised, $12 / 10 / 2020$

Accepted, 19/12/2020

\section{Keywords}

Evaluation

Integration

Madaris curriculum

Psychology

Islamic Education

\section{ABSTRACT}

This study evaluated the Madaris curriculum integration for Muslim primary education in Mindanao. It assessed the psychological effects of such integration on teachers and students in Arabic writing and reading, religiosity, Islamic values, and teacher professional development. This qualitative and quantitative research used a descriptive-evaluative design. The purposive sampling method was used to collect data using a questionnaire which was analyzed statistically. This study showed that the psychological effects of integrating teachers and students to Arabic writing and reading, religiosity, Islamic values, and teacher professional development worked well. Both teachers and students demonstrated the ability to write and read Arabic, values about God, Islam, people, the nation, and the environment.

This is an open access article under the CC-BY-SA license.

\section{Citation:}

Abdulkarim, K.A., \& Suud, F.M. (2020). Evaluation of Madaris Curriculum Integration for Primary Muslim Education in Mindanao: An Assessment of The Influence of Psychology. International Journal of Islamic Educational Psychology, 1(2), 89-100. DOI: https://doi.org/10.18196/ijiep.v1i2.9736 
Abdulkarim \& Suud | Evaluation of Madaris Curriculum Integration for Primary Muslim Education in Mindanao: An Assessment of The Influence of Psychology

\section{INTRODUCTION}

Education is the core of human resource development. Education aims to instill young people's values and culture to shape their identity as citizens and communities. It also aims to equip citizens with the ability to pursue economic opportunities within and outside the region (Khaidir, E., \& Suud, F. M. (2020). Whether simple or complex, every society has a different pattern of transmitting cultural values and norms to its young and potential members. Some people have used educational mediation for the preservation of cultural values. The impact of foreign culture and values applications is still visible in most Muslim societies. It might directly affect Muslim intellectuals' writings, especially in education. As the impact also emphasizes society's development, politics, and law rather than the individual, mind, or soul. The characteristics of an ideal society and the foundations of education, as envisioned by Islam, are challenged by Western theory and philosophy. Some authors have observed that Muslims have enslaved their bodies and souls. Before the rise of Islam, Islamic education's basic structure was continually being revised and changed according to popular trends and changes from the west (Gamon, 2017).

The world has witnessed Muslims' suffering in the Philippines with how faith, the light of spiritual life, and devotion to Islamic teachings could be maintained in an environment based on a secular philosophy of life. Muslim intellectuals in the Philippines have shown their unwavering aspiration and concern for the transformation of Islamic education as an instrument to save the community from Western education. Most Filipino Muslims have considered globalization's ongoing process and its manifestation in the Philippine education system as a new form of colonialism (Sali, A. H. A., \& Marasigan, A. C. 2020). Its impact on society marks the beginning of a new intellectual "tag to mark" episode between Muslims and Christians in the Philippines. Filipino Muslims, particularly those living in non-Muslim areas, assimilate into a secular education that challenges the foundations of a Moro identity (Rodriguez, 1993).

It has always been every Muslim educator's aspiration to witness the revival of Islam in the Philippines through Islamic institutions and unite societies regardless of their socio-cultural and historical diversity. Part of Filipino Muslims' unrelenting optimism has become a reality as the government reconsiders its policy of developing a Muslim Islamic education system by establishing Islamic higher education institutions and implementing related laws to teach the Arabic language. In private and public schools, the integration of Madaris into the national education system is carried out. The government's development policy towards Muslims is based on the Philippine Constitution, stating that: "The state must consider the customs, beliefs, and interests of the national cultural community in the formulation and implementation of state policies" (Part II, Article XV). The 1982 education law recognized the need to increasingly promote cultural communities' right to relevant education to 
Abdulkarim \& Suud | Evaluation of Madaris Curriculum Integration for Primary Muslim Education in Mindanao: An Assessment of The Influence of Psychology

participate in national development (Rodriguez, 1993). Part 3, paragraph 8 of the Act states: "States should promote the right of national cultural communities to exercise their right to develop themselves in the context of their culture, traditions, interests, beliefs and recognize education as an instrument for their maximum participation in national development. and in ensuring their involvement in achieving national unity."

Responding to state policies recognizing the need to consider Islamic education of Muslims and their culture as part of Philippine culture, the government established the following programs: National Integration Council, Mindanao State University, Institute of Islamic Studies under the University of the Philippines, MSU-Shari'ah Center, King Faisal Center for Research and Islamic Studies, Code of Muslim Personal Laws (PD 1083) and the establishment of Sharia courts as part of national law. In line with the implementation of this law, the government recognizes the institution's six units of Sharia Law in the Bachelor of Laws offered by Western Mindanao State University (WMSU) and Mindanao State University (MSU), the College of Law and jurisprudence courses offered at other public universities. The establishment of this institution is based on the Philippines' philosophy and educational goals. As stated in the Constitution, all educational institutions are under the supervision and subject to state regulations (Section 8 Article XV).

Among the steps taken by the government to advance Islamic education for Muslims is the issuance of a Letter of Instruction (LOI) No. 71-A. It allows and authorizes Arabic as the language of instruction in schools and districts in the Philippines, and LOI-1221, which acknowledges the accreditation and integration of madrasas into the Philippine education system (Tamano.1995).

The most notable development issued by the government for Muslim education in the South is the power of the Autonomous Region of Muslim Mindanao (ARMM). As provided in part 1 of Article XIV R.A. 9054, it is known as the Extended ARMM Law. It states that "Local governments must establish, maintain, and support as the main priority a complete and integrated quality education system and adopt an educational framework that is meaningful, relevant and responsive to the needs, aspirations, and aspirations of the community in the region." Thus, the Muslim Mindanao Law No. 14 regulates the accreditation of madaris in the local education system so that these schools are supported to make it part of the national education standard. Besides, other regional regulations have been implemented, and seminars and conferences have been called. Task forces and councils have been formed to accommodate and strengthen madaris to recognize their contributions to Muslims and the nation.

Questions that arise over the government's seriousness in establishing these programs, given their long delay in implementation. Some of these programs 
Abdulkarim \& Suud | Evaluation of Madaris Curriculum Integration for Primary Muslim Education in Mindanao: An Assessment of The Influence of Psychology

have been issued and are technically in effect for years with no administrative tools to enforce them. Various studies have been conducted on Muslim education in Mindanao. Research reveals that little improvement has been made in the nearly two decades despite the government's concerted efforts to introduce educational programs in Muslim Mindanao (Gamon, 2017).

\section{The Policy of Integration and its Implications to Islamic Education}

The Integration Policy assumes that an integrated curriculum, public textbooks, and unified policies, combined with efforts to increase Filipino Muslim access to secular education, will gradually resolve Muslim-Christian tensions. The government's secular approach in addressing Filipino Muslims' educational needs, such as the establishment of CNI, MSU, Institute of Islamic Studies-UP, has failed to resolve conflicts between Muslims and Christians in the Philippines.

Some authors have observed that Moro people have long rejected integration. Due to the euphemistic equivalent of assimilation, a subtle form of 'deMuslimization or [de-Islamization'] of the younger generation of Muslims, there is a detour towards Christianization. It is influenced by the Philippine government's conceptions and understanding. National culture is defined as a Christian culture, and therefore integration means assimilation from Muslims to Christian culture. Despite the determination of Muslims to reject the government's integration policy, Muslim educators are working hard to encourage young Muslims to take advantage of the government's new educational opportunities (Tan, 1981).

Among other reasons for the Philippine government to change its policy in the South, it has become ASEAN members' concerns and other Muslim countries' attention. The religious sentiments of the Muslim world provide a powerful force for Filipino Muslims. Although Mindanao's propaganda issue is not a religious conflict, the Organization of the Islamic Conference (OIC) has never wavered in its moral support for Filipino Muslims' justice. It seeks its influence for justice - the solution to the Mindanao problem (Gowing, 1982).

Some believe and view the development program to "heal the wounds" caused by the national government's injustice and the Christian population towards Muslims in the Southern Philippines (Kamlian, J. A. 2003). National policymakers know how much Muslims have been hurt by the government's failure to provide them with education following their Islamic culture and traditions. One Muslim educator pointed out, "It is in this area that there is consensus among Muslims that they are treated indifferently, if not ignored by their government. They believe that inequalities exist in educational resources and opportunities, particularly at school, from the lowest to the highest" (Batua, 1989). Perhaps, the resolution made by Muslim leaders to develop neglected Muslim education will also help convince the government to change its education policy in Muslim autonomous regions, particularly in establishing 
Abdulkarim \& Suud | Evaluation of Madaris Curriculum Integration for Primary Muslim Education in Mindanao: An Assessment of The Influence of Psychology

institutions where Arabic and Islamic studies can be offered. It is a fair move for the government because their respective governments permit and authorize Islamic and Arabic studies in individual schools and universities in Muslimdominated areas in most of its neighbors like Singapore and Thailand.

Some people still believe that the Philippine government is developing Islamic education by establishing several institutions and implementing several related laws. They do not realize Filipino Muslims' aspirations to develop and improve their education in Arabic and Islamic Studies, but as a reluctant concession and perhaps a move right to secularize Muslim youth (Batua, 1989).

\section{METHOD}

This study used a mixed-method, which was qualitative and quantitative research. The purposive sampling method collected data using a questionnaire checklist, which was statistically analyzed by means and percentages. This study's subjects were students of public schools with an integrated Madaris curriculum across the City of Cotabato and Zamboanga, which offer structured education and sequential learning with the formal education system. They offer kindergarten and elementary school programs.

This study's respondents were 70 Arabic Language Teaching and Islamic Learning teachers and 200 Muslim students in these schools with an integrated Madaris curriculum. The survey questionnaire was used for public school teachers and Muslim students between Islamic Values Education (ALIVE) Teachers and students. The questionnaire list for ALIVE Teachers had two parts. Part I consisted of age, gender, status, ethnic affiliation, monthly income, educational qualifications, and service years. Part II was the appropriate questions through the evaluation of Program Management, Curriculum, Teaching Materials, Training and Professional Development of Asatidz, Funding Resources, and Advocacy of Madrasah Curriculum Standards. Respondents evaluated the question items from four Likert scales, namely: Strongly Agree (SA), Agree (A), Disagree (D), Strongly Disagree (SD).

\section{RESULTS AND DISCUSSION}

\section{Socio-Economic Profile of the Teachers and Students}

Using Erikson's developmental stages, most of his teachers were middle-aged adults, while most of his students were school-aged children. In terms of marital status, almost all teachers were married, while all students were single. The majority of teachers and students were women. The ethnic affiliations of the teachers and students were Maguindanaon, Sama, and Tausug. They were the dominant ethnic group in the research locations. The city of Zamboanga is mostly home to the Sama and Tausug tribes, while Magindanaon originates from Maguindanao Province. From an educational perspective, in secular education, 
Abdulkarim \& Suud | Evaluation of Madaris Curriculum Integration for Primary Muslim Education in Mindanao: An Assessment of The Influence of Psychology

all teachers hold a Bachelor of Science degree in Islamic Education and Studies. Some have master's degrees. Half of the teachers completed tertiary education and a half in a senior secondary school in Madrasah education. His students all attended public primary schools.

The teachers' tenure coincided with the year Madaris is integrated into public schools. The majority of teachers reported teaching for ten years or more. Most teachers' monthly salary or allowance is only Php 6,000.00, which is within the current minimum wage of Php280.00 in Zamboanga City and Php295.00 in Cotabato City. It is also the department's designated program funding support for those teaching in public schools.

\section{The Enabling Factors in the Integration of Madaris Curriculum in the Public Schools}

The teachers generally agreed on a Management Program with a functional organizational structure, objectives, duties, responsibilities, proper assignment distribution, and the standard madrasah curriculum. Teachers work in harmony with one another. There are proper means of giving and receiving orders and requests. The implementation of the Standard Madrasah Curriculum began in 2005-2006, a year after classes were passed virtually like regular classes on weekdays.

The Madaris Education Curriculum, integrated into public schools, met the Department of Education (DepEd) Regulation Number 40 of 2011 (Standard Curriculum for Public Elementary Schools and Private Madaris). The Refined Elementary Madrasah Curriculum (REMC) promotes Philippine national identity while preserving Filipino Muslims' cultural heritage (Tan, 1981). This curriculum also builds Muslim students' smooth movement from private Madrasahs to public schools with the ALIVE Program. Furthermore, it unites the long history of educational dichotomy among Muslims (Kulidtod, 1994). The curriculum provides theoretical knowledge based on specialization and learning to apply theory to real problems. The curriculum answers the needs of the professional and technical readiness that graduates need. It also integrates values that reflect national customs, culture, and traditions in applicable cases (Bustaman, 2011).

The teachers agreed that there was periodic supervision, assessment, and updating of the curriculum where lecturers and students participated in curriculum development and revision. Teachers reported that the school offered Arabic to develop functional literacy in Arabic to enable students to read and understand the Koran and Hadith. The school offered Islamic Studies, which included History, Hadith, Aqidah, and Fiqh to develop knowledge and skills to read the Koran, understand hadith, and applied the values learned in everyday life (Meiers, 2007). It also aimed to understand the life story of the Prophet 
Abdulkarim \& Suud | Evaluation of Madaris Curriculum Integration for Primary Muslim Education in Mindanao: An Assessment of The Influence of Psychology

Muhammad (SAW) from childhood to adulthood, prophethood era and imitate the values in it. The teachers also agreed that aqidah developed an understanding of beliefs related to Aqidah Islamiyyah, the basis of Islam, and the Oneness of Allah SWT.

The teachers continued to agree that schools offering Islamic education would guide people to become Makadiyos (for God), Makabayan (for the country), Makakalikasan (for nature) in Makatao (for the people) and make them agents in promoting brotherhood, peace, and unity, justice, and equality (Abdulkarim, 2016). Finally, the ALIVE subject is a sufficient source of religious knowledge taught to students to practice Islam.

ALIVE teachers experienced English training and a particular teaching method using BEAM modules before teaching in public schools (Lamla, M. T. 2018). ALIVE teachers attended the training by utilizing teacher training modules for Azatid and teacher trainers from a list of Master Teachers and other qualified personnel in district and division offices funded from the training budget or savings from MOOE. Teachers complete professional development programs regularly and continuously to improve their overall skills, knowledge, or ability to deliver qualified alternative learning system programs. The school holds regular training and seminars for teachers (Nordstrum, 2012).

Funding for program support comes from the DepEd State Budget. Schools do not receive Special Education Funds from Local Government Units (LGU). In Arabic, respondents are good at writing Arabic, reading simple words, and using greetings in daily conversations. They understand manuscript letters with the correct use of punctuation, solutions to problems based on experience, and other learned knowledge in any situation. In this research, the respondents were not good at using figurative words and expressions, directly or indirectly, and different sentences in discussions and explanations (Harya, 2017).

In Islamic Studies, respondents were competent to memorize several short verses of the Qur'an such as Surah Al-Fatihah, Al-'Asr, Al-Kautsar, Al-Kafirun, AlIkhlas, Al-Falaq, and An-Nas. They were also good at Islamic identity, beliefs, characteristics, and responsibilities of a Muslim. They understood parts of the Qur'an, such as a chronological order of surahs, memorization, understanding, and interpretation of some of the Prophet's hadiths.

The Hindering Factors in the Integration of Madaris Curriculum in the Public Schools

Teaching materials were where problems arise. The school did not have funding for instructional support programs and provisions for in-house seminars for ALIVE Teachers (Watson, 1989). The textbook was 1: 1 per subject to student ratio, and the school had a ratio of more than 1:45 teachers to students. 
Abdulkarim \& Suud | Evaluation of Madaris Curriculum Integration for Primary Muslim Education in Mindanao: An Assessment of The Influence of Psychology

According to one of the ALIVE teachers, he said that "The textbook is limited. It is 1: 5 (one book for every five students) per grade or more. We don't distribute books to students because it is not enough. We borrow books from the library whenever we have class and return them afterward. For the Teacher-Student ratio, 1:50 per class in both Arabic and Islamic subjects ".

Teacher salary issues were ignored despite teachers' time spent on their duties and responsibilities (Suud, 2018). The students lacked in memorizing the Koran, such as Surah At-Takathur, Al-Qari'ah, Al-'Adiat, Az-Zalzalah, Al-Bayyinah, and As-Shams. Likewise, they had insufficient knowledge and understanding of the Koran and the true meaning of revelation. Department of Education (DepEd) lacked disseminating information about the Standard Madrasah Curriculum without forums, dialogue, orientation, brochures, or bulletins.

\section{The Psychological Effects on the Integration of Arabic Language and Islamic Values Education (Alive) to Teachers and Students}

The teachers emphasized that the integration of Arabic had a good psychological effect on them. Teachers developed competencies in listening, speaking, reading, and writing skills. In teaching ALIVE to public school children, listening, speaking, and writing skills in Arabic are improved. Generally, teachers demonstrate the values of Makadiyos, makatao, makabayan, and makakalikasan about oneself and Allah SWT (Franco, J. 2017). These are the values of BuMaka (for Allah SWT); Makatao (for the People) values refer to relationships with parents, siblings, family members, close relatives, and teachers and parents (Suud, et al., 2019 classmates, and other people at school (Fitriah, M., \& Madjid, A. 2020). The Makabayan value refers to the relationship with society, animals, and other creations. The last is the Makakalikasan value, which refers to one's relationship with the surrounding environment and the community.

In Islamic studies, teachers positively stated that it had a good psychological effect on them . Respondents were good at memorizing several short verses of the Qur'an and the Islamic identity, beliefs, characteristics, and responsibilities of a Muslim (Khafidah, W., Wildanizar, W., Tabrani, Z. A., Nurhayati, N., \& Raden, Z. (2020). The teachers could instill the belief in Allah's oneness to form excellent and productive believers seeking Allah's pleasure.

In Islamic Values, the students demonstrated the values of Makadiyos (for God), Makatao (for the people), Makabayan (for the country), Makakalikasan (for nature or a sustainable environment). The students were aware of their relationship with themselves, their parents, siblings, family members, close relatives, teachers, parents, classmates, people in society, other creations, and surroundings. In the ALIVE Advocacy Program, respondents generally agreed that this program would help Muslim youths and adults become religious, 
Abdulkarim \& Suud | Evaluation of Madaris Curriculum Integration for Primary Muslim Education in Mindanao: An Assessment of The Influence of Psychology

insightful about Islam, and preserve Islamic culture, values, and practices.

\section{CONCLUSION}

The evaluation of the integration of the Madaris curriculum in public schools showed driving and inhibiting factors. After the approval of the Guidelines for Utilization of Funds for the Madaris Education Program, the Standard Curriculum for Public Elementary Schools and Private Madaris was implemented in 2005-2006. The study found that in Zamboanga City, with 98 Barangays, only 20 public schools had integrated Madaris Education with the public school curriculum.

Despite integrating madaris education into public schools with Project Funding Support from the department of education and designation by region and division, program limitations and financial management contributed to schools' inadequacy in Muslim communities. It resulted in Muslims' historical marginalization in a predominantly Catholic country, low ALIVE teacher salaries, lack of learning materials, and professional educators. These issues will hamper the ideals of an authentic and appropriate Islamic education for the Bangsamoro people if not fostered. It happens not only in Mindanao but in the entire Philippines, where Muslims are scattered to find a bright future for their children. With the new President of the Republic of the Philippines coming from Mindanao, optimism for increased political and administrative support for integrating the madaris curriculum in all public schools is growing.

The Department of Education should increase its Project Fund Support to integrate Madaris education in public schools. There must be a budget allocation for in-house seminars from ALIVE Teachers. Sufficient textbooks for students with such a number that the ratio is 1: 1 (one book per student) per subject. ALIVE teacher salaries must be increased to equal the salary of regular public school teachers. There needs to be proper socialization of the Standard Curriculum for Private Madaris through dialogue orientation, distribution of brochures, and by holding a series of forums. There should be an improvement in figurative words and expressions and various sentences in discussion and explanation. There needs to be an improvement in memorizing long surahs from the Qur'an, knowledge, understanding the Qur'an, and the true meaning of revelation. The problems, challenges, and prospects of Madaris Education, which is one of the Higher Education Commission's research agendas, recommends that research be carried out on the problems at hand. Further studies are needed to measure the extent of the integration of the Madaris Curriculum in Public Schools. 
Abdulkarim \& Suud | Evaluation of Madaris Curriculum Integration for Primary Muslim Education in Mindanao: An Assessment of The Influence of Psychology

\section{REFERENCES}

Abdulkarim, Kamarodin Abas. "Evaluation On The Integration Of Madaris Curriculum For Muslim Basic Education In Mindanao, Philippines: Assessing The Psychological Effect," N.D., 34.

Bustaman-Ahmad Kamaruzzaman. et.al. "Islamic Studies and Islamic Education in Contemporary Southeast Asia", Mainstreaming Madrasah Education in the Philippines: Issues, Problems and Challenges by Carmen Abubakar . 2011.

Bloom, Benjamin S. 1994. "Taxonomy of Educational Objectives." New York:

D. Gamon, Alizaman "Islamization of Education in the Philippines. from http:/ / i-epistemology.net/v1/ education/ 98-islamization-of-education-in-the philippines.html Retrieved on 7 May 2017 p.1

Franco, J. (2017). Uncertainty in Duterte's Muslim Mindanao. Southeast Asian Affairs, 297-312.

Gowing, Peter G. “Religion and Regional Cooperation: The Mindanao Problem and ASEAN", Journal Institute of Muslim Minority Affairs, Vol. IV, 1982, No.1-2. pp.19-20

Harya, Trisna Dinillah. "An Analysis Of Figurative Languages Used In Coelhos's Novel Entitled 'Alchemist.'” Premise Journal:Issn Online: 2442-482x, Issn Printed: 2089-3345 5, No. 2 (May 8, 2017): 46. Https:/ /Doi.Org/10.24127/Pj.V5i2.815.

Fitriah, M., \& Madjid, A. (2020). Honesty: A Multidimensional Study as Motivation for National Character Building. Hayula: Indonesian Journal of Multidisciplinary Islamic Studies, 4(1), 99-116.

Kulidtod, Zainal Dimaukom. "Islamic Educational Policies In The Philippines: Its Evolution And Current Problems" 1, No. 1 (2017): 11.

Kamlian, J. A. (2003). Ethnic and Religious Conflict in Southern Philippines: A Discourse on Self-Determination, Political Autonomy, and Conflict Resolution. Emory University, Atlanta, 4..

Khaidir, E., \& Suud, F. M. (2020). Islamic education in forming students'characters at as-shofa Islamic High School, pekanbaru Riau. International Journal of Islamic Educational Psychology, 1(1), 50-63.

Khafidah, W., Wildanizar, W., Tabrani, Z. A., Nurhayati, N., \& Raden, Z. (2020). The Application of Wahdah Method In Memorizing The Qur'an for 
Abdulkarim \& Suud | Evaluation of Madaris Curriculum Integration for Primary Muslim Education in Mindanao: An Assessment of The Influence of Psychology

Students of SMPN 1 Unggul Sukamakmur. International Journal of Islamic Educational Psychology, 1(1), 37-49.

Lamla, M. T. 2018). Issues and Concerns on Madrasah Education in Basilan, Philippines: The Asaatiz Perspectives. International Journal of Novel Research in Education and Learning, 5(4).

Lemu S.A (1994), -An Approach to the Development of Qur'anic Schools in the Contemporary Societyll. Paper presented at the National Seminar on Qur'anic Education organized by NTIL, and UNICEP, held at Kaduna.

Macaraya Batua. "Solutions to the Mindanao Conflict", p. 104-105.

Macaraya, Tocod D. Sr. (1989). "Meaningful Autonomy: The Key to Unity, Solidarity, and National Progress," A paper delivered during the First International Islamic Symposium for Peace and Solidarity, held on August 7-9, 1989, Philippine Plaza Hotel, Manila-Philippines.

Meiers, Marion. “Teacher Professional Learning, Teaching Practice and Student Learning Outcomes: Important Issues." In Handbook of Teacher Education, edited by Tony Townsend and Richard Bates, 409-14. Dordrecht: Kluwer Academic Publishers, 2007. https://doi.org/10.1007/1-40204773-8_27.

Nordstrum, Lee E. “Teacher Supply, Training and Cost in the Context of Rapidly Expanding Enrolment: Ethiopia, Pakistan and Tanzania," n.d., 26.

Resolution No. 12 of the 10th Islamic Conference in Fez, Kingdom of Morocco, July 8-12, 1979

Rodriguez, Lolita. “A Madrasah General Education Program for Muslim Mindanao (second printing of published Ph.D thesis), 1993

Sali, A. H. A., \& Marasigan, A. C. (2020). Madrasah Education Program implementation in the Philippines: an exploratory case study. International Journal of Comparative Education and Development.

Suud, F. M. (2018). Kepemimpinan Transformasional dan Implikasinya pada Pembentukan Budaya Jujur di Sekolah. Sukma: Jurnal Pendidikan, 2(2), 261-286.

Tamano, Salipada S., during the First Mindanao Educators Congress, September 27-29, 1995, Garden Orchid Hotel, Zamboanga City.

Tan, Samuel K. “Sulu Under the Eagle's Shadow, 1899-1948”, Mindanao Journal, 
Abdulkarim \& Suud | Evaluation of Madaris Curriculum Integration for Primary Muslim Education in Mindanao: An Assessment of The Influence of Psychology

Vol. 8, nos. 1-4, 1981-1982. Cited in Luis Lacar, Neglected Dimensions in the Development of Muslim Mindanao.

Tocod D. Macaraya Sr. "Meaningful Autonomy: The Key to Unity, Solidarity and National Progress," A paper delivered during the First International Islamic Symposium for Peace and Solidarity, held on August 7-9, 1989, Philippine Plaza Hotel, Manila-Philippines.

Watson, John. “Blending Learning: The Convergence of Online and Face-to-Face Education," 1989. 